he adds that "its diphycercal (or perhaps heterocercal) condition" is also common to many groups. Well, I have never seen a "heterocercal" Palcoospondylus in spite of the many specimens with well-preserved tails which have come under my observation. Nor have I, although I must have examined nearly two hundred examples of the little creature in question, many of them in a much better state of preservation than the one which is the special subject of this paper, ever seen anything like the shadowy furrows interpreted by Dr. Dean as pectoral fin-rays.

Therefore I must, in conclusion, state my belief that the examination of this specimen leaves the question of the affinities of Palceospondylus precisely where it was after I had written my last paper on the subject.

My warmest thanks are, however, due to Dr. Bashford Dean for his kindness and generosity in sending his specimen again across the Atlantic for re-examination by British palæichthyologists.

\title{
2. On a Collection of Mammals from North and
} North-west Australia. By R. Colletr.

[Received February 10, 1897.]

\section{(Plate XXIII.)}

Mr. Knut Dahl, a young naturalist, returned to Norway in May 1896, after spending three years, from 1893 to 1896 , in South Africa and Australia for the purpose of collecting zoological specimens for the University of Christiania.

In June 1894 he arrived at Port Darwin, in North Australia, and at once commenced his researches in the inner districts of Arnhem Land. He subsequently visited Victoria River (south of Arnhem Land), and finally remained at Roebuck Bay, Northwest Australia, from October 1895 to February 1896, where he likewise obtained interesting collections. He collected altogether examples of 34 species of Mammals, 31 of which may be identified. Besides this, several others were observed without being procured. Two of the species of which specimens were brought home I consider new to science (Pseudochirus dahlii and Sminthopsis nitela), and several of the others are rare and seldom met with in collections.

I shall therefore append a short account of the Mammals which have been brought home and which are all preserved in the Zoological Museum at Christiania, and add to it a short description of the most important of the places visited, together with their peculiarities, from the reports I have received of them from Mr. Dahl.

I owe my thanks to my friend $\mathrm{Mr}$. Oldfield Thomas for having assisted me in determining some of the more doubtful specimens.

Characteristic of the whole of Arnhem Land is a mighty forest, which more or less covers the entire country.

Port Darwin, the first locality visited. is characterized by flat, 
open forest-land, extending to the very banks of the Adelaide River. The forests are mainly composed of various sorts of Eucalyptus, and are denser than any seen elsewhere in Arnhem Land. Numerous small watercourses intersect the plains, and are surrounded by jungles of bamboo-cane, large trees of Ficus, and, finally, a species of palm closely allied to Areca.

In the next district, Daly River, one again meets with the same forest-land, and, on the whole, the same kind of trees; but the forests are more open, changing here and there into large plains, which in some places are covered with swamps and lagoons, surrounded by Melaleuca-trees, and in others assume a sandy desert-like appearance. Hermit Hill lies a little to the southward of Daly River, and on the whole possesses the same natural features.

About 100 miles inland from the mouth of the Daly River the country consists of broken tableland; Mt. Showbridge lies to the eastward of this and is of considerable height.

Glencoe (or Fountain Head) has low woods and large open plains.

Mary River, which flows to the northward, rises partly in a peculiar granite formation, which extends up to the railway at Union Town, and partly from permanent springs in the great central tableland, whence Alligator River also flows northward, and whence Katherine River flows towards the south and west, subsequently joining the Daly River, and bounding Arnhem Land in the south. The great tableland is covered with large forests and permanent water-springs.

In the neighbourhood of Victoria River the district consists of broken sandstone ranges, covered with Spinifex grass and gumtrees.

Roebuck Bay, North-west Australia ( $18^{\circ} \mathrm{S}$. lat.), is desert-like country, covered with scrub and lakes.

Fam. P t E R P ODID

1. Pteropus scapulatus, Peters, 1862.

Pteropus scapulatus, Dobs. Cat. Chir. Brit. Mus. p. 41 (1878); Ogilby, Cat. Austral. Mamm. p. 80 (1892).

N. Australia: Daly River, Aug. 17th, 1894 (one specimen).

Skin. The coloration of the fur is as described in the immature specimens ( $P$. elseyi, Gray, 1866); a paler reddish-brown collar round the neck, and no traces of white shoulder-tufts.

The woolly hairs covering the lower surface of the forearm and adjacent parts of the wing-membrane are of a pale greyish-yellow colour.

Length of forearm $138 \mathrm{~mm}$.

Slcull.-

Length of the skull (about)

$59 \mathrm{~mm}$.

Breadth across zygomatic arches...... 35 ",

Length of dental series .......... 23 ", 
Dentition normal. Upper $m^{2}$ is in this specimen considerably larger than $i^{2}$.

Hab. Common on the River Daly (Arnhem Land). Several specimens were shot, but only one preserved.

2. Pteropus gouldi, Peters, 1867.

Pteropus gouldii, Dobs. Cat. Chir. Brit. Mus. p. 60 (1878); Ogilby, Cat. Austral. Mamm. p. 79 (1892).

N. Australia: Port Darwin, June 17th, 1894 (two specimens). Daly River, Aug. 17th, 1894 (one specimen).

Skin. The specimens belong to the typical form, with the back of the head and neck ferruginous brown.

Skull. All the specimens are young, and have no traces of parietal crests; but, in spite of their youth, all the teeth are worn. Length of dental series $29 \mathrm{~mm}$.

$H a b$. Very numerous in Arnhem Land, especially close to the big rivers. At Roebuck Bay (N.W. Australia) Flying-Foxes were rarely seen and none were procured.

\section{Fam. VESPERTILIONID A.}

3. Scotophilus greyi, Gray, 1843 (Dobs. 1877).

Scotophilus greyii, Dobs. Cat. Chir. Brit. Mus. p. 263 (1878); Ogilby, Cat. Austral. Mamm. p. 92 (1892).

W. Austialia: Roebuck Bay, Nov. 13th, 1895 (two specimens).

Skin. One is a young male, the other a full-grown female (length of forearm $33 \mathrm{~mm}$.), containing an embryo of the size of a large pea.

Hab. The commonest species at Roebuck Bay, but no Bat was plentiful there.

4. Nyctophilus timoriensis (Geoffr.), 1806.

Nyctophilus timoriensis, Dobs. Cat. Chir. Brit. Mus. p. 172 (1878); Ogilby, Cat. Austral. Mamm. p. 87 (1892).

N. Australia: Daly River, July 1894 (four specimens).

N.W. Australia: Roebuck Bay, Nov. 1895 (one specimen).

Skin. Two specimens are males, length of forearm $+1-42 \mathrm{~mm}$; and three females with the forearm 38,38 , and $40 \mathrm{~mm}$. One of the specimens (from Daly River) shows the peculiarity that the ears are not joined, there being no trace of the connectingmembrane on the forehead.

$H a b$. Very numerous on Daly River, rarer at Roebuck Bay. Generally seen shortly before sunset close to the houses.

5. Chalinolobus nigrogriseus (Gould), 1856.

Chalinolobus nigrogriseus, Dobs. Cat. Chir. Brit. Mus. p. 251 (1878) ; Ogilby, Cat. Austral. Mamm. p. 91 (1892).

N.W. Australia : Roebuck Bay, Nov. 30th, 1895 (one specimen). 
Skin. The single specimen is a male; length of forearm $35 \mathrm{~mm}$. side.

Skcull. The minute first upper premolar is absent on the left

Hab. Rare at Roebuck Bay, not seen in Arnhem Land.

6. Vesperdgo tendis (Temm.), 1835-41.

Vesperugo tenuis, Dobs. Cat. Chir. Brit. Mus. p. 226 (1878) (Sumatra, Java, Borneo).

N.W. Australia: Roebuck Bay, Nov. 1895 (one specimen).

Skin. The specimen agrees in all details with Dobson's description. Length of cubitus $30 \mathrm{~mm}$. Colour greyish brown, scarcely darker at the base of the hairs; beneath more ashy.

The muzzle (with the glandular prominences) covered with short hairs, interspersed with a few longer hairs; only the nostrils are perfectly naked.

Skull. Outer cusp of first upper incisor shorter than inner cusp ; upper $i^{2}$ a little shorter than outer cusp of $i^{1}$.

Hab. V. tenuis has been recorded from Sumatra, Java, and Borneo, but had not previously, so far as is known, been found in Australia.

At Roebuck Bay (N.W. Australia) it was rare, like the other species.

Fam. RHIN OL O PHID

7. Hipposiderus muscinus (Thos. et Doria), 1886.

Phyllorhina muscina, Thos. et Doria, Ann. Mus. Civ. Stor. Nat. Genova, ser. 2, vol. iv. p. 201 (1886).

N. Australia: Mary River, May 7th, 1895 (two specimens).

Skin. Both specimens are females (like those obtained by d'Albertis in New Guinea). Length of forearm $43 \mathrm{~mm}$. and $44 \mathrm{~mm}$. The nose-leaf is alike in both, and perfectly agrees with the figure in Thomas and Doria's description of the typical specimens.

$H a b$. This species is new to the Australian fauna. It had hitherto only been found on the Fly River, in New Guinea, by d'Albertis.

In Arnhem Land it was not uncommon on the Mary River, and several specimens were found resting in the caves, some few hanging close together.

Fam. EM B A L L ON U R I D

8. Taphozous australis, Gould, 1854.

Taphozous australis, Dobs. Cat. Chir. Brit. Mus. p. 382 (1878) Ogilby, Cat. Austral. Mamm. p. 96 (1892).

N. Australia: Mary River, May 10th, 1895 (four specimens).

Skin. One specimen is a male, the rest females; no air-sac is developed on the throat of the male.

Length of forearm $67-69 \mathrm{~mm}$.

$H a b$. Numerous on the Mary River, found in the caves in company with Hipposiderus muscinus. 


\section{Fam. C A N I D}

9. CANis DINGo, Blumenb., 1790.

Canis dingo, Ogilby, Cat. Austral. Mamm. p. 123 (1892).

N. Australia : Hermit Hill, Aug. 12th, 1894 (one specimen and one skull). Daly River, Aug. 1894 (one specimen). S. Alligator River, June 15th, 1895 (one specimen).

Skin. The three specimens belong to the red variety. The size seems to be inferior to those from Queensland which are preserved in the Christiania Museum ; length of four skulls 183-190 mm.

$H a b$. Only the red variety was seen in Arnhem Land; but black specimens were known by the natives.

\section{Fam. M U R I D x.}

10. Conilurus penicillatus (Gould), 1842.

Conilurus penicillatus, Ogilby, Cat. Austral. Mamm. p. 117 (1892).

N. Australia : Hermit Hill, Aug. 15th, 20th, 1894 (five specimens). Daly River, Oct. 1894 (three specimens). Adelaide River, Dec. 12th, 1894 (one specimen). Mary River, May 15th, 1895 (one specimen).

Skin. There are ten specimens in all : two of the skins (Hermit Hill, Aug. 1894) have the tail white-tipped (length of white tip $26 \mathrm{~mm}$.); in all the other specimens the tail is black throughout. In the single autumn specimen (Mary River, May 1895) the hairs on the tail are very short and adpressed.

Skull. In a full-grown specimen, with worn teeth, the length of the skull is $44 \mathrm{~mm}$., the breadth $23 \mathrm{~mm}$.

Foramen palatinum reaching to or a little beyond the first molar.

The anterior border of the os interparietale forms a straight line, the posterior one a rounded one.

$H a b$. Numerous all over Arnhem Land, and in great numbers on the rivers on the lowlands. Most of the specimens procured were taken from holes in the trees, but they were also seen close to and within the houses.

Native name: Pelke.

\section{Conilurus boweri (Ramsay), 1886.}

? Hapalotis macrura, Peters, Monatsb. Akad. Wissensch. Berlin, 1876 , p. 355 , pl. i. (1876).

Hapalotis boweri, Ramsay, Proc. Linn. Soc. New South Wales, 2nd ser. vol. i. p. 1153 (1886).

Conilurus boweri, Ogilby, Cat. Austral. Mamm. p. 116 (1892).

N.W. Australia: Roebuck Bay, Dec. 8th, 1895 (one specimen, a female). Roebuck Bay, Dec.16th, 1895 (two half-grown young ones, in spirit).

Skin. The specimen (a female) is not perfectly adult, the teeth being unworn and the posterior molars not yet fully developed. 
Length of the body, with head, about $150 \mathrm{~mm}$., length of tail $250 \mathrm{~mm}$. Consequently the proportions of the body to the tail is as three to five, thus considerably longer than in the typical $C$. boweri, and agreeing in that respect with $C$. macrurus, Peters.

The colour is exactly as in Ramsay's description of C. boweri. From a little in front of the ears, down the back of the head, and the central portion of the back and on the root of the tail is a broad distinct band of golden yellow, rufescent on the nape. The tail is brown for one-seventh of its base, the remainder white; towards the tip the hairs are somewhat longer than on its inner parts, but no distinct brush is present.

This specimen from Roebuck Bay thus has the proportions of the body in accordance with C. macrurus, and the colour with $C$. boweri; there is therefore much reason to believe that the two species are identical.

The two half-grown young ones have both a length of $96 \mathrm{~mm}$. (head and body); the tail was 103 and $110 \mathrm{~mm}$. Thus the tail was proportionally much shorter than in the larger specimen, and perfectly in accordance with Ramsay's description of his C. boweri. The colour, too, was as in the type specimen; the hairs of the tail evenly short to the tip, and no trace of a brush was developed.

Mammo four.

S7cull. Hardly distinguishable from that of $C$. penicillatus.

$\mathrm{Hab}$. Rare in the neighbourhood of Roebuck Bay, not found in Arnhem Land. Several were seen within the houses.

Native name: Katkomba.

12. Conilurus hirsutus (Gould), 1842.

Conilurus hirsutus, Ogilby, Cat. Austral. Mamm. p. 117 (1892).

N. Australia: Hermit Hill, Aug. 8th-15th, 1894 (eleven specimens and two fœtuses). Daly River, Oct. 7th, 1894 (one specimen). Mount Showbridge, March 15th, 1895 (two specimens). Katherine River, July 13th, 1895 (one specimen).

Fotus. Besides the 15 specimens, mostly full-grown, there are two fœtuses (taken from a female at Hermit Hill, A ug. 15, 1894) of the size of a nearly full-grown mouse. Vibrissæ already welldeveloped.

In one the placenta was still adherent; it is very large and thick, rather oblong, its diameters being $23 \mathrm{~mm}$. and $27 \mathrm{~mm}$.

The number of fotuses is never more than two.

Slcin. Size very large. Measured on the skins of full-grown specimens the length of body and head is about $315 \mathrm{~mm}$., the tail about 340-360 $\mathrm{mm}$.

Occiput and neck in all tinged with rusty yellow; belly yellowish white. The feet are varied above with black and rusty yellow; the hands are black, but in most specimens the long hairs which cover the claws are whitish.

Skull. Length $67 \mathrm{~mm}$; breadth $32 \mathrm{~mm}$. Foramen palatinum not reaching the anterior border of the teeth series. Anterior 
border of os interparietale strongly convex ; posterior also convex, its lateral angles pointed.

Teeth remarkably like those of $C$. penicillatus.

$H a b$. Common all over Arnhem Land, very numerous on the plains around the Daly River. Generally it was found hidden in holes of the trees, and numbers were taken by hand by the natives.

Number of young only two.

Native name: Nunjala.

\section{Mus rattus Rufescens, Gray, 1837 .}

N. Australia: Glencoe, Jan. 1894 (one specimen).

Skin (in spirit). Length of head and body $160 \mathrm{~mm}$., tail 198 mm. Number of rings on the tail 205.

Of the different varieties of $M$. rattus described by Thomas ${ }^{1}$ and Blanford ${ }^{2}$, the present specimen comes nearest to Mus rufescens, Gray, the colour being rufous brown, with a yellowish tint along the sides; the belly and lower parts of head are whitish, hands and feet more reddish grey. The fur is mixed with fine spines ${ }^{3}$.

$H a b$. Not rare in the storehouses of the colonists in Arnhem Land.

\section{Hydromys chrysogaster fulto-lavatus, Gould, 1863.}

Hydromys fulvolavatus, Ogilby, Cat. Austral. Mamm. p. 102 (1892).

N. Austratia: Daly River, Aug. 4th, 1894 (one specimen). Daly River, Aug. 4th, 1894 (four young ones in spirit). Daly River, Aug. 13th, 1894 (one young one in spirit).

Skin. The full-grown specimen, a female, belongs to the western variety (H.fulvolavatus, Gould, 1863). Whiskers mixed black and white; extreme tip (one inch) of tail white.

$H a b$. Found nearly everywhere in the watercourses in Arnhem Land.

\section{Fam. MACR O PODID .}

\section{Macropus antilopinus (Gould), 1841.}

Macropus antilopinus, Thos. Cat. Mars. Monotr. Brit. Mus. p. 21 (1888); Ogilby, Cat. Austral. Mamm. p. 59 (1892).

N. Australia: Hermit Hill, Aug. 9th, 1894 (one specimen, female). Glencoe, Jan. 1895 (skull, male). Victoria River, April 13th, 1895 (one specimen, young).

Skin. The specimen from Victoria River is a young one, the second a female, scarcely full-grown. Through an accident the

1 Proc. Zool. Soc. 1881, p. 533 (Mus alexandrinus).

2 'Fauna of British India,' Mammalia, p. 406 (1888-91).

3 Besides the specimen of $M$. rattus there are in the collection three specimens (skins or in spirit) of two or three species of Mus from North Australia. But without larger series from the different localities it is hardly possible at present to work them out satisfactorily ; and as the description of isolated specimens of this genus only causes further confusion, I prefer to omit them altogether. 
skin of a nearly adult male (from Glencoe) was destroyed, and its skull only preserved.

The coloration of the young and the female agree in most details with Thomas's description. The fingers and toes are, however, yellowish white to the claws, and the tail, too, is rufous white throughout, not becoming darker towards the tip.

Skull. In the male the length is $174 \mathrm{~mm}$., the breadth $103 \mathrm{~mm}$. The greatest breadth across the inflated nasal chamber is $49 \mathrm{~mm}$. The specimen is not perfectly adult; the line between the zygomatic processes will touch the anterior part of $m^{4}$. The skull of the young female has a length of $147 \mathrm{~mm}$., breadth $87 \mathrm{~mm}$.

MaLE.-Teeth. Persistent set not yet developed, the milk $p^{4}$ being still present. It is short, with a weak root; its length scarcely exceeding the breadth of $\mathrm{m}^{\mathrm{t}}$.

In the lower jaw $m^{1}$ is almost aborted on both sides, its premolarlike crown being pressed obliquely in the space between (the normal) $m^{2}$ and the milk $p^{4}$.

Female. - Teeth as in the male, but $m^{1}$ in lower jaw is normal. The milk $p^{4}$ in both jaws very small and directed obliquely forwards.

$H a b$. Common in Arnhem Land in the neighbourhood of hills, generally seen in herds. Also found on Victoria River. It was very wary and difficult to approach.

Native name: Koppo (male); Kondaltburu (female).

16. Macropus agitis (Gould), 1841.

Macropus agilis, Thos. Cat. Mars. Monotr. Brit. Mus. p. 42 (1888); Ogilby: Cat. Austral. Mamm. p. 54 (1892).

N. Australia: Port Darwin, June 1894 (four specimens). Daly River, July-Aug. 1894 (four specimens and one embryo). Victoria River, April 1895 (one specimen). Katherine River, July 1895 (three specimens).

N.W. Australia: Roebuck Bay, Nov. 1895 (five specimens and three embryos).

Skin. There are in the collection 17 skins (mostly with skulls), four embryos or young ones from pouch, and several skulls extra.

Young from pouch. Length from snout to anus about $150 \mathrm{~mm}$., tail $97 \mathrm{~mm}$.

Eyes still closed. Naked; hairs on snout just traceable. No teeth visible. (Roebuck Bay, Nov. 1895.)

Another young one, length from snout to anus about $200 \mathrm{~mm}$., tail $148 \mathrm{~mm}$. (size of a squirrel). Still almost perfectly naked, the eyelids and vibrissæ developed. Lower incisors visible. (Roebuck Bay, Nov. 1895.)

Skull. 20 skulls, in different stages of development, are in the collection (length between $68 \mathrm{~mm}$. and $152 \mathrm{~mm}$.).

Teeth. I give some remarks on the teeth in a few of these stages.

Young stage (a specimen from the pouch). Length of the skull 
$68 \mathrm{~mm} . P^{3}$ and the milk $p^{4}$ are fully developed; $m^{1}$ is just emerging from the alveolus.

Middle stage. Two skulls, length $121 \mathrm{~mm}$. and $126 \mathrm{~mm}$., are just in the stage when $p^{3}$ and the milk $p^{4}$ are at the point of being changed. In both specimens the persistent $p^{4}$ is already developed in one of the upper jaws; in the other jaw $p^{3}$ and the milk $p^{4}$ are still present, but the persistent $p^{4}$ is (in the largest specimen) visible above their roots through a hole in the maxillary. In the lower jaw on one side, too, the persistent $p^{4}$ is developed, on the other side not. sizes :-

Adult stage. Two full-grown specimens, having the following

Male: length 152 , breadth $80 \mathrm{~mm}$.

Female : " 140 , " 74 ,

Two other skulls belong, too, to old specimens ${ }^{1}$, but are smaller, their length being 129-136 mm.

In all these four skulls $m^{4}$ is fully developed; a line between the tips of zygomatic processes will touch the middle (or in the old male the posterior part) of $m^{4}$.

Between the middle stage and the adult there are nine skulls (length from $119 \mathrm{~mm}$. to $146 \mathrm{~mm}$.), none of which have $m^{4}$ fully developed. The line between the tips of zygomatic arches will touch the middle of $\mathrm{m}^{3}$, in the youngest specimens the posterior part of $m^{2}$.

Between the middle stage and the young one there are four skulls (length between $118 \mathrm{~mm}$. and $123 \mathrm{~mm}$.). $P^{3}$ and the milk $p^{4}$ are still present; $\mathrm{m}^{3}$ is only half-developed.

Hab. The commonest species in Arnhem Land and at Roebuck Bay, and met with everywhere along the great rivers ; especially numerous in the big bamboo-jungles.

Native names: Ma, Bulak.

17. Macropus robustus (Gould), 1840.

Macropus robustus, Thos. Cat. Mars. Monotr. Brit. Mus. p. 22 (1888); Ogilby, Cat. Austral. Mamm. p. 58 (1892).

N. Australia: South Alligator River, June 17th, 1895 (one specimen, a female, with a young one from its pouch).

Skull. Length of the skull (female) $139 \mathrm{~mm}$., breadth $77 \mathrm{~mm}$. The last molar has not yet reached its full height.

$H a b$. In the central tablelands, Arnhem Land, scarce, solitary.

Native name: Tjikurr (male); Tjugeri (female).

18. Petrogale concinna, Gould, 1842.

Petrogale concinna, Thos. Cat. Mars. Monotr. Brit. Mus. p. 71 (1888); Ogilby, Cat. Austral. Mamm. p. 48 (1892).

N. Austratia: Daly River, July 2lst, 1894 (one specimen). Mary River, May 1895 (seven specimens and two embryos).

Skin. In all specimens the white tips of the hairs on the back

${ }_{1}$ Sex undetermined, but probably both females. 
are very conspicuous, and give the orange-rufous back a grizzled silvery appearance.

The terminal pencil of the tail is rather variable in colour, in some specimens being almost brownish black.

Skull. Perhaps none of the specimens are perfectly adult, as the last molar has in no case reached its full growth. Length of the largest specimen (a male) $78 \mathrm{~mm}$., breadth $44.5 \mathrm{~mm}$.

Interorbital space in larger specimens slightly concave; the fronto-nasal suture strongly concave or forming an obtuse angle (open in front).

Posterior palatal foramina large, reaching from front or middle of $\mathrm{m}^{2}$ to middle of $\mathrm{m}^{4}$. The bony bridge behind the foramina very thin, with many small openings.

Teeth. The dentition of this species is rather peculiar, and the skulls in the collection seem as if they had five molars and no premolar. The anterior of the teeth is, however, the milk $p^{4}$, which has exactly the shape of a true molar.

The eight skulls represent three different stages.

Young stage. In two young specimens (length of skull $49 \mathrm{~mm}$. and $59 \mathrm{~mm}$.) both premolars $\left(p^{3}\right.$ and the milk $\left.p^{4}\right)$ are present. $P^{3}$ has a normal shape, not very different from that in other species; it has four cusps (the anterior indistinctly divided in two), with shallow notches between them. Its length equals that of $p^{4}$.

Middle stage. One skull, length $73 \mathrm{~mm}$., breadth $42 \mathrm{~mm} . P^{3}$ is still present in the right side of the upper jaw, but has fallen out on the other side. and below. Consequently this tooth seems to be changed at the time when $m^{3}$ is appearing.

Nearly adult stage. Five skulls, length $72 \mathrm{~mm}$. to $78 \mathrm{~mm}$. As stated above, $\mathrm{m}^{4}$ has not reached its full development in any of these, although one of them belongs to the mother of one of the young ones.

The perfectly molar-like $p^{4}$ is present in all ; most likely it is changed at a very late period, and it may even be an open question whether it is ever changed at all.

$H a b$. Common on the granite on the western heads of the river Mary. On Daly River it was met with in one locality only (about a hundred miles from the river mouth).

Native name: Bolwak.

19. Petrogale brachyotis, Gould, 1840.

Petrogale brachyotis, Thos. Cat. Mars. Monotr. Brit. Mus. p. 69 (1888); Ogilby, Cat. Austral. Mamm. p. 49 (1892).

N. Australia: Daly River, July 20th-21st, 1894 (three specimens and one young in spirit). S. Alligator River, April 14th, 1895 (one specimen). Mary River, May 11th-14th, 1895 (two specimens and one embryo). Union Town, Aug. 16th, 1895 (one specinen).

Skin. There are seven specimens, besides one young from the pouch and one embryo.

To the detailed description of $\mathrm{Mr}$. Thomas I may add that in all the specimens there is a faint dark line down the centre of the 
occiput and neck, almost obsolete in some, but more distinct in others. In the latter it reaches to between the white shouldermarkings.

Eyelids black, hands and feet dark brownish grey.

The lower side of the tail is greyish white almost to the tip; the longer dark brown hairs are forming a brush chiefly on the upperside of its terminal third or fourth.

A young from the pouch (length $100 \mathrm{~mm}$. without tail) is still almost naked; snout hairy.

Teeth. Only one of the skulls at hand is from an adult specimen, its length is $100 \mathrm{~mm}$., breadth $53 \mathrm{~mm}$. It is a male, with the innermost molar fully developed and the persistent $p^{4}$ functional.

Another skull, a younger male, length $90 \mathrm{~mm}$., breadth $46 \mathrm{~mm}$., is in the stage where the persistent $p^{4}$ is showing above the root of $p^{3}$ and the milk $p^{4}$, both of which are still present, but much worn. The first traces of $m^{4}$ are visible through the maxilla.

The other skulls are all younger, with $p^{3}$ and the milk $p^{4}$ still in place.

The milk $p^{4}$ is broad, rather like a molar, but not so perfectly molar-like as is the case in $P$. concinna.

$H a b$. Common in Arnhem Land in broken hilly country; also seen on the Victoria River.

Native names: Petpungo, Doria.

20. Onyohogale unguifera (Gould), 1840.

Onychogale unguifera, Thos. Cat. Mars. Monotr. Brit. Mus. p. 74 (1888); Ogilby, Cat. Austral. Mamm. p. 48 (1892).

N. Australia: Glencoe, Jan. 1895 (one specimen).

N.W. Australia: Roebuck Bay, Feb. 1st-20th, 1896 (four specimens).

Slcull. Posterior palate (os palatinum) sieve-like, with numerous vacuities; a few holes in the maxillary part of the palate.

None of the specimens are perfectly adult, the innermost molar not having reached its full height in any of them.

Teeth. The persistent $p^{4}$ is very small, with three very distinct cusps and deep notches between them. It is much like $p^{3}$, but narrower in front. The milk $p^{4}$ is unlike both, rather molar-like, but a little smaller than $m^{1}$.

The youngest specimen, a female, length $92 \mathrm{~mm}$., has both $p^{3}$ and the milk $p^{4}$ functional. $M^{4}$ has not yet appeared.

The next specimen, also a female, length $93 \mathrm{~mm}$., has $p^{3}$ and the milk $p^{4}$ functional in all jaws except in the upper left, where $p^{3}$ has fallen out, and the persistent $p^{4}$ is showing itself above the root of the milk $p^{4} ; m^{4}$ is half-developed.

In two larger specimens, length from 97-101 mm., $p^{4}$ is functional, but $m^{4}$ not yet fully up.

Canines mostly present.

$H a b$. In Arnhem Land this Kangaroo was only met with around Fountain Head and Glencoe; at Roebuck Bay, it was common amongst the Melaleuca scrubs on the edges of open plains.

Native name: Korrabbal. 
21. Bettongia lesuedri (Quoy \& Gaim.), 1824.

Bettongia lesueuri, Thos. Cat. Mars. Monotr. Brit. Mus. p. 112 (1888); Ogilby, Cat. Austral. Mamm. p. 41 (1892).

N.W. Australia: Roebuck Bay, Nov.-Dec. 1895 (seven specimens, three young ones, one embryo).

There are in the collection, besides the seven skins, three young ones from the pouch (size of a rat), one embryo (length about $26 \mathrm{~mm}$.), and eight extra skulls, all from Roebuck Bay.

Skin. In some specimens the tail shows traces of a low crest of darker colour towards the tip. Back rather variable in colour, greyish in some, more reddish in others. Tip of tail not white in the seven adult specimens at hand; but in two young ones (from the pouch, size of a small rat) the tip is white for $\frac{1}{4}$ to $\frac{1}{2}$ inch. Arms and legs pale brown, hands darker reddish brown.

Skcull. The largest skull has a length of $71 \mathrm{~mm}$., breadth $45 \mathrm{~mm}$. In some specimens the frontal crests meet posteriorly and form a short and low sagittal crest.

Teeth. $P^{4}$ has 10 external grooves (in some specimens 9 ).

In one specimen the canine has two cusps, very distinct on the left, less on the other side.

$H a b$. Very numerous around Roebuck Bay, burrowing in the sand-hills.

Native name: Jalva.

\section{Fam. PHA L AN GER I D}

22. Trichosurts vulpecula (Kerr), 1792.

Trichosurus vulpecula, Thos. Cat. Mars. Monotr. Brit. Mus. p. 187 (1888); Ogilby, Cat. Austral. Mamm. p. 78 (1892).

N. Australia; Daly River, July-Aug. 1894 (eleven specimens, three embryos, two young in spirit, one skeleton). Katherine River, July 13th-14th, 1894 (two specimens).

Skin. These specimens seem to form a distinct race (var. arnhemensis), characterized by their inferior size and the scantily clothed tail.

Length of head and body (measured from the skin) about $360 \mathrm{~mm}$.; tail $250 \mathrm{~mm}$.

The exterior two-thirds of the tail is naked below, and on the sides, and the black hairs form a crest along the upperside, but leaving the tip itself almost bare.

Colour variable, in most specimens (typical) grizzled grey, in others reddish brown, with all transitions between them. Distal part of the tail black; in one specimen it has a faint trace of white on the extreme tip.

Chin blackish, as in the type form; the reddish-brown longitudinal patch on the centre of chest also present in most specimens.

Slcull. Nine skulls, all of which with the teeth fully developed have the following size :-

Largest specimen : length 80 ; breadth $48 \mathrm{~mm}$. 


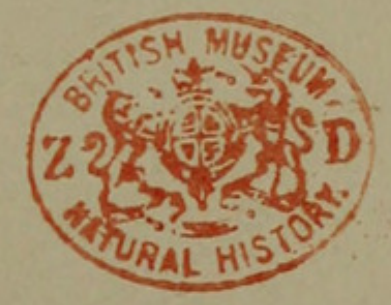




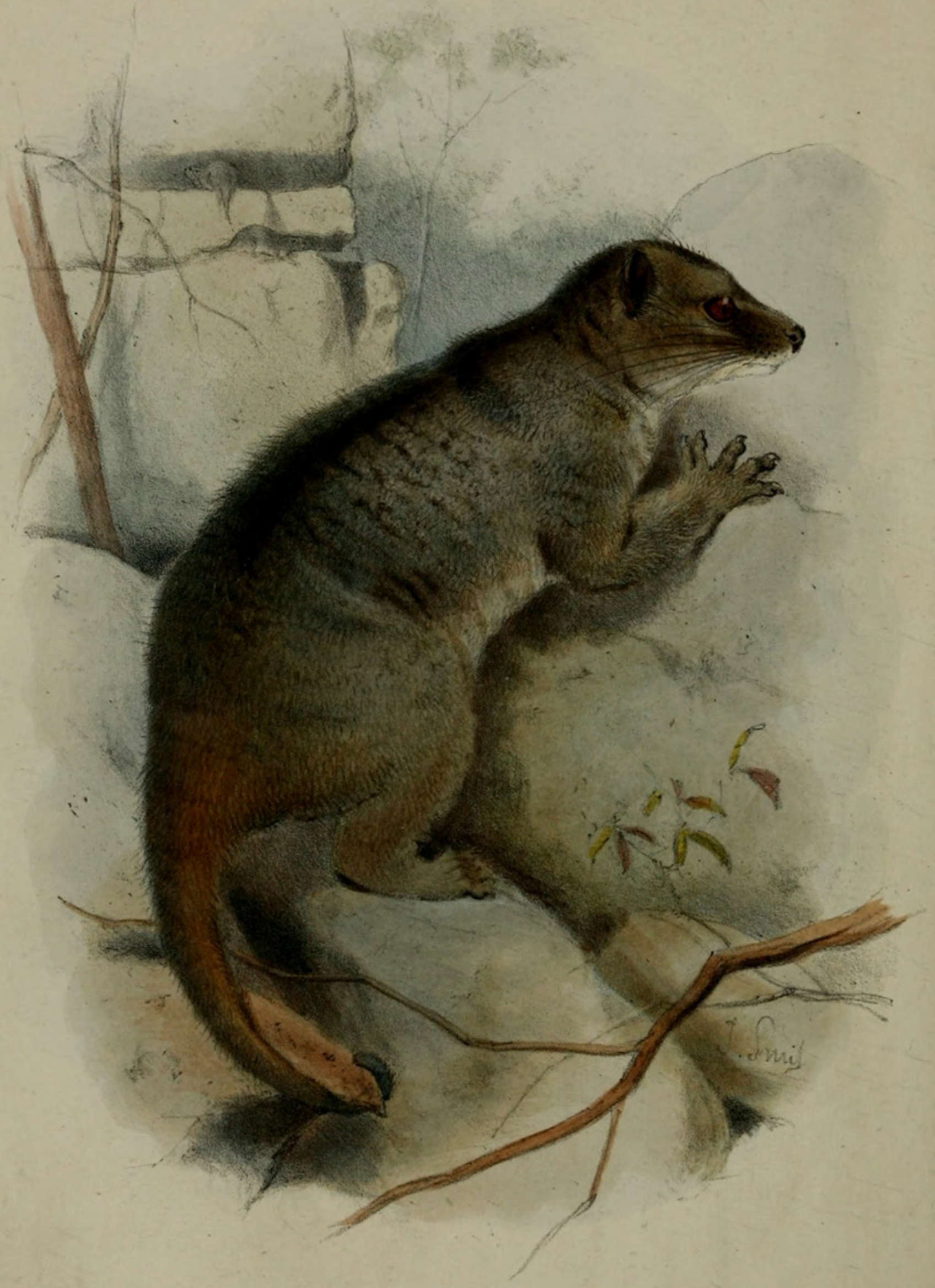


Smallest specimen : length 65 ; breadth $42 \mathrm{~mm}$.

Two younger specimens, length of the skull in both $60 \mathrm{~mm}$., are just in the stage where the persistent $p^{4}$ is pushing out the milk $p^{4}$ (which is still present). $M^{4}$ is just traceable in the bottom of the gum.

Hab. Common in Arnhem Land and at Roebuck Bay, but nowhere very numerous. All the specimens seen were of the same small size. It was much in request by the natives for food.

Native names: Uia, Uidda.

\section{Pseudochirus dahli, Coll., 1895. (Plate XXIII.)}

Pseudochirus dahli, Collett, Zoolog. Anzeiger, no. 490, Dec. 1895, p. 464 (1895).

N. Australia: Mary River, May-June 1895 (eight specimens, one young in spirit, one embryo). Union Town, Aug. 16th, 1895 (two specimens, one skeleton).

There are in the collection ten specimens of this species (with skull), and one skeleton, besides one young and one embryo in spirit.

\section{General Characters.}

Size large. Head small. Tail short (about half the length of the body), tip almost naked. Ears short.

Fur long and woolly; colour reddish grey above; a blackish median frontal line. Tail more rufous, not white-tipped. Breastspot rufous.

Muzzle very narrow ; meatus auditorius inflated; orbital ridges parallel and not uniting behind; posterior palate with large foramina.

Incisors and molars strong, intermediate teeth very feeble or absent. Upper $i^{2}$ elongated horizontally, lower $i^{1}$ lancet-shaped.

\section{Plastic Characters.}

Size large. Length of the fresh animal (tail included), according to Dr. Dahl, 80-90 cm.

(In the skin the length to the root of tail sometimes exceeds $450 \mathrm{~mm}$., tail 270 ; together a total of about $720 \mathrm{~mm}$.)

Head proportionally very small, as well as the ears.

Tail very short, its length in some specimens not exceeding half the length of the body (head included).

Fur very thick and woolly, much like that of $P$. archeri; the tail thickly clothed on the upper half or two-thirds of its length, the thick covering gradually tapering towards the tip, which is almost naked (only a few short adpressed hairs). The lower part of the tail entirely naked for two-thirds of its length from the tip.

Ears short and broad, long-haired on their posterior roots, more thinly clothed towards their tips; inside they are well haired along the prominent folds.

Proc. Zoor. Soc.-1897, No. XXII. 
Rhinarium very narrow, the height being nearly double its breadth.

Pupil vertical.

Claws short, rather blunt, almost hidden by the hairs.

\section{Colour.}

General colouring resembling that of $P$. peregrinus.

The back is grizzled grey with more or less reddish hue, all the longer hairs having white tips. The rump more rufous.

Head grey. A whitish spot (sometimes indistinct) above and below the eye. A median dark line, more or less conspicuous, extends from between the eyes to the occiput; in some specimens this line is continued (very indistinctly) along the middle of the back.

Ears with a small patch of white on the lower part of their posterior border. Vibrissæ black.

Tail rufous like the rump, the white-tipped hairs here being scarcer. The thin hairs on the tip are sometimes blackish.

Lower parts from chin to tail whitish; a rusty spot on the middle of the chest. Lower part of the tail reddish, like the upper, only a little clearer.

Legs coloured above like the back, below whitish ; hairy covering of the claws in some specimens blackish.

A half-grown specimen is coloured like the adult; the white tips of the hairs less conspicuous, aud the rusty spot on the chest hardly visible.

\section{Skeleton.}

Limbs short and strong.

Femur broadly expanded in its upper part; its length not exceeding that of the pelvis, or even shorter.

Fibula also broadly expanded above, its greatest breadth at its upper extremity being more than that of tibia.

Tibia and fibula greatly bowed and diverging.

Humerus also comparatively broad at its upper and lower extremities ; ulna and radius rather diverging in the middle.

Os sacrum formed by three vertebræ, the transverse processes of which are all coalescent.

Caudal vertebra. The number is in one specimen 23 , in another 24 , besides a rudimentary one in the tip, together 24-25.

\section{SKULL.}

Small in proportion to the body. Its length in the largest specimen $72 \mathrm{~mm}$., the breadth $43 \mathrm{~mm}$.

Muzzle very slender and pointed (even narrower than in Dactylopsila trivirgata), not swollen.

Nasals narrow, rather flattened above, reaching to about the level of $i^{1}$, and but little expanded behind; the naso-frontal angle very deep, bifid, the points reaching the vertical from the middle of $m^{3}$. Length of the suture from maxilla to sutura frontalis 
almost equalling the greatest combined breadth of the nasals. Naso-premaxillary suture not longer than the naso-maxillary suture. Nasal notch rather deep, nasals projecting about $5 \mathrm{~mm}$. beyond their junction with the premaxillæ.

Interorbital region very deeply concave in the middle, its edges raised up into high, prominent, sharp-edged ridges, running parallel and not uniting behind.

Meatus auditorius externus swollen (as in P. peregrinus); bullæ not inflated.

Anterior palatine foramina short, barely extending backwards to the level of $p^{1}$.

Posterior palate with two large foramina, extending from the anterior border of $m^{2}$ to beyond $m^{4}$, and only separated from the border of choanæ by a thread-thick bony bridge.

\section{TeEth.}

Teeth strong. The diastema between $i^{3}$ and $c$ is $2-3 \mathrm{~mm}$.; length of molars 1-3 together about $13 \mathrm{~mm}$.

The typical dental formula is :-

$$
i . \frac{1.2 .3}{1.0 .0} \text { or } \frac{1.2 .3}{1.2 .0} ; \quad c . \frac{1}{0} ; \quad p . \frac{1.0 .3 .4}{0.0 .0 .4} ; \quad m . \frac{1.2 .3 .4}{1.2 .3 .4} \text {. }
$$

Upper jaw.-Incisors: anterior incisors separated in front; $i^{2}$ elongated horizontally, its antero-posterior diameter equalling twice that of $i^{3}$.

Distinct diastemata in front of and behind the canine.

Canine present, small, half the size (or less) of $i^{3}$; in one specimen it is absent on one side.

Premolars. $P^{1}$ present or absent, rudimentary, smaller than the canine; in three of eleven skulls it is absent on one side ${ }^{1}$.

$P^{2}$ absent ; in one of eleven skulls (the largest of all) it is present but perfectly rudimentary, its crown hardly being raised abore the gum ${ }^{2}$.

$P^{3}$ and $p^{4}$ always present; size of $p^{3}$ about half that of $p^{4}$, the latter about two-thirds the size of $m^{1}$.

Molars large, typical; length of molar series reaching $17 \mathrm{~mm}$.

Lower jaw.-Incisors. $I^{1}$ long, lancet-shaped, broadest in the middle (as in Ps. albertisi); upper and lower edge with an angle separating the enamel-covered cutting portion from the root, which is narrower.

$I^{2}$ present or absent, always minute; in eleven skulls it is present in five, absent in six. $I^{3}$ always absent.

Canine absent.

Premolars. $P^{1}$ absent or present; in four skulls of eleven it is present, minute ${ }^{3}$.

${ }^{1}$ The dental formula in these three specimens is: on one side $p \cdot \frac{0.6 .31}{0.0 .0 .4}$, on the other side (typical) $\frac{1.0 .3 .4}{0.0 .0 .4}$.

2 In this specimen, a male, the formula is on both sides: $p \cdot \frac{1.2 .3 .4}{0.0 .0 .4}$.

${ }^{3}$ Dental formula in these specimens : $p \cdot \frac{1.0 .3 .4}{1.0 .0 .4}$. 
$P^{2}$ and $p^{3}$ always absent; $p^{4}$ present, long, tricuspid, rather broad behind.

Molars as in upper jaw.

\section{Young, in SpIrit.}

Size of a half-grown rat. Length from snout to vent about $100 \mathrm{~mm}$., tail $81 \mathrm{~mm}$.

Body still almost naked; the vibrissæ only are well developed, forming 7 rows. A tuft of long hairs on the wart-like protuberance on the inner surface of the forearm.

Lower incisors half developed.

Pads on hands and feet very large, with exceedingly fine transverse striations. Number of palmar pads 5 : one very large posteroexternal, one large pollical, three anterior (as usual only one below 3rd and 4th finger).

Sole-pads 6 , one very large postero-external, two pollicals, three anterior (one only below the connected 2 nd and 3 rd toe).

The small pads below the tip of each finger and toe are comparatively large and distinct.

Claws proportionally very short.

\section{LOCALITY.}

$H a b$. The Rock Phalanger inhabits the granite formations of the western heads of the River Mary, Arnhem Land, and is tolerably numerous there on the great central tableland.

During the daytime it hides amongst the colossal boulders, and leaves the rocks only at night, when it ascends the trees in search of food. This consists principally of the soft parts of a kind of berry with large stone, like a giant cherry (belonging to the genus Zizyphus?).

It never sleeps in hollow trees, like its congeners, but it will, when roused, occasionally take refuge in a tree.

Native name: Wogoit.

\section{Petaurus breviceps, Waterh., 1838.}

Petaurus breviceps, var. typicus, Thos. Cat. Mars. Monotr. Brit. Mus. p. 156 (188 $)$; Ogilby, Cat. Austral. Mamm. p. 34 (1892).

N. Australia: Mt. Showbridge, March 16th, 1895 (one specimen). Mary River, May 1895 (one skull).

Skin. Length of female from snout to vent (measured from the skin (about $170 \mathrm{~mm}$., tail (to tip of hairs) $230 \mathrm{~mm}$.

Worsal stripe strongly marked; tip of tail (in the single specimen) white.

Young. Two young ones (size of a mouse) in spirit. Length from snout to vent $65 \mathrm{~mm}$., tail $85 \mathrm{~mm}$. Tip of tail white.

One young (a little larger). Length from snout to vent $85 \mathrm{~mm}$., tail $110 \mathrm{~mm}$. Tip of tail black. Dorsal stripe well marked in all ; tail still short-haired. 
Skull. Length in two adult specimens (male and female) $37 \mathrm{~mm}$., breadth $26 \mathrm{~mm}$.

Hab. Met with both in Arnhem Land and at Roebuck Bay, but scarce. It was generally seen along the coast, more rarely inland.

Native name : Lambalk.

Fam. Pe R A ME L I D E.

25. Perameles macrura, Gould, 1842.

Perameles macrura, Thos. Cat. Mars. Monotr. Brit. Mus. p. 234 (1888); Ogilby, Cat. Austral. Mamm. p. 22 (1892).

N. Australia: Daly River, July-Aug. 1894 (four specimens and four extra skulls). Katherine River, July 15th, 1895 (one specimen). Mt. Showbridge, Nov. 11th, 1895 (one young, in spirit).

Skull. Size of largest specimen : length $78 \mathrm{~mm}$., breadth $36 \mathrm{~mm}$.

Young (size of a mouse). Shields on lower surface of middle toe broad, undivided (one series).

$H a b$. Common in Arnhem Land: generally found sleeping in hollow trees.

Native name: Koppol.

26. Perameles obesula (Shaw), 1793.

Perameles obesula, Thos. Cat. Mars. Monotr. Brit. Mus. p. 231 (1888); Ogilby, Cat. Austral. Mamm. p. 23 (1892).

N.W. Australia: Roebuck Bay, Nov.-Dec. 1895 (three specimens, one young in spirit, seven embryos, one skeleton).

Slcull. Size of largest specimen $59 \mathrm{~mm}$., breadth $28 \mathrm{~mm}$.

Young (size of a mouse). Shields on lower surface of middle toe divided (two series).

$H a b$. Common at Roebuck Bay in the dry coast country (not seen in Arnhem Land).

Fam. D A S Y U R I D F.

27. Dasyurus hallucatus, Gould, 1842.

Dasyurus hallucatus, Thos. Cat. Mars. Monotr. Brit. Mus. p. 269 (1888); Ogilby, Cat. Austral. Mamm. p. 15 (1892).

N. Australia: Daly River, Sept. 7th, 1894 (one skull). Mt. Showbridge, Dec. 4th, 1894; March 10th, 1895 (two specimens). Adelaide River, Dec. 15th, 1894 (one specimen). Mary River, May 10th, 1895 (one specimen). Union Town, May 30, 1895 (one specimen).

Skin. Five specimens, all males. All belong to a dark variety, the ground-colour of the body being of a more or less deep brownish black, with the tips of the hairs yellowisb.

Head with smâll and indistinct spots on the front; legs spotted in some specimens, in others unicoloured.

T'ail unspotted; on upper base coloured like the back (or rather 
lighter, the hairs here being brownish yellow throughout); outer half and lower surface blackish.

Size rather large; length of an adult male (measured in the skin) from tip of snout to vent about $330 \mathrm{~mm}$., tail $295 \mathrm{~mm}$. (the tail thus is both relatively and absolutely longer than in specimens described by Thomas, $l$. c. p. 270).

Skcull. Size of an adult male : length $69 \mathrm{~mm}$., breadth $44 \mathrm{~mm}$., nasals $25 \mathrm{~mm}$., upper $\mathrm{m}^{1-3} 13 \mathrm{~mm}$., length of palate $35 \mathrm{~mm}$.

$H a b$. Throughout Arnhem Land, but nowhere common. It lives on trees and amongst rocks.

Native names: Jirian, Tjabbo.

28. Phascologale penicillata (Shaw), 1800.

Phascologale penicillata, Thos. Cat. Mars. Monotr. Brit. Mus. p. 294 (1888); Ogilby, Cat. Austral. Mamm. p. 12 (1892).

N. Australia: Daly River, Oct. 10th, 1894 (two young ones). Fountain Head, May 5th, 1895 (one specimen). Union Town, May-July 1895 (five specimens).

N.W. Australia : Roebuck Bay, Feb. 3rd, 1896 (one specimen).

Young. Two specimens (size of a mouse), male and female. Tail-brush already well developed. Upper $i^{1}$ not yet visible, $c$ halfgrown, $m^{3}$ not developed. $P^{4}$ is the milk premolar, very small, about half the size of $p^{3}$.

$H a b$. Common in the interior of Arnhem Land, more scarce at Roebuck Bay.

Native name: Wombo.

29. Phascologatue flatipes leucogaster, Gray, 1841.

Phascologale flavipes, var. leucogaster, Thos. Cat. Mars. Monotr. Brit. Mus. p. 291 (1888); Ogilby, Cat. Austral. Mamm. p. 13 (1892).

N. Australia: Daly River, July 1894 (one specimen, in spirit).

Skin. The tail being imperfect, the specimen cannot be determined with absolute certainty, but there is nothing to prevent it from being the north-western form of $P$. flavipes.

$H a b$. Only one specimen from Arnhem Land.

30. Sminthopsis nitela, n. $\mathrm{sp}$.

Diagn. Allied to S. leucopus (Gray), but characterized by a central stripe from muzzle to forehead, incrassated tail, and smooth (not striated) pads.

Measurements (from specimens in spirit) :-

$\begin{array}{lll} & \begin{array}{c}\delta . \\ \mathrm{mm} .\end{array} & \begin{array}{c}q . \\ \mathrm{mm} .\end{array} \\ \text { Length of head and body } \ldots \ldots \ldots \ldots \ldots & 89 & 70 \\ \text { Tail } \ldots \ldots \ldots \ldots \ldots \ldots \ldots \ldots \ldots & 99 & 88 \\ \text { Sole, from heel to tip of claws } \ldots \ldots \ldots & 22 & 18\end{array}$




\section{$2 \mathrm{BHL}$ Biodiversity Heritage Library}

Collett, Robert. 1897. "On a collection of mammals from north and north-west Australia." Proceedings of the Zoological Society of London 1897, 317-336.

View This Item Online: https://www.biodiversitylibrary.org/item/97165

Permalink: https://www.biodiversitylibrary.org/partpdf/69600

\section{Holding Institution}

Natural History Museum Library, London

\section{Sponsored by}

Natural History Museum Library, London

\section{Copyright \& Reuse}

Copyright Status: Public domain. The BHL considers that this work is no longer under copyright protection.

This document was created from content at the Biodiversity Heritage Library, the world's largest open access digital library for biodiversity literature and archives. Visit BHL at https://www.biodiversitylibrary.org. 